\title{
CHARACTERIZATION OF THE FISHES AND OF SUBSISTENCE FISHING IN THE PANTANAL OF MATO GROSSO, BRAZIL
}

\author{
OLIVEIRA, R. D. de ${ }^{1}$ and NOGUEIRA, F. M. de B. ${ }^{2}$ \\ ${ }^{1}$ Master Course in Ecology and Conservation of Biodiversity, Federal University of Mato Grosso, \\ CEP 78060-900, Cuiabá, MT, Brazil \\ ${ }^{2}$ CNPq researcher Bio-sciences Institute, Federal University of Mato Grosso, CEP 78060-900, Cuiabá, MT, Brazil. \\ Correspondence to: Rosenil Dias de Oliveira Calegari, Av. das Azaléia n. 525, Cidade Jardim, CEP 13566-710, São \\ Carlos, SP, Brazil, e-mail: prosenil@ iris.ufscar.br \\ Received November 13, 1998 - Accepted November 23, 1999 - Distributed August 31, 2000
}

(With 7 figures)

\begin{abstract}
Fishing is one of the oldest human activities in the Pantanal of Mato Grosso in Central Brazil. In the of Bento Gomes River Basin (Pantanal of Poconé) the presence of fishermen is very common. The objective of this study is to describe the fishing activity in the basin in view of the elaboration of proposals for the sustainable use of this natural resource. Of the 256 fishermen that were registered most are fishing for their subsistence $(92 \%)$ and the rest $(8 \%)$ are occasional fishermen (locally called "de lufada" fishermen). "Traíra" (Hoplias gr. malabaricus) and "piranhas" (Serrasalmus marginatus, Serrasalmus spilopleura and Pygocentrus nattereri) were the species most frequently captured for human consumption. The fishing is more intensive during the ebb season and at the beginning of the drought season, when the waters begin to recede for the river channel, as the catch is facilitated by the concentration of fishes at the river margin. The fishermen and their families consume fish three to four times a week, twice a day. Fish meat is one of the only means of obtaining animal protein for dozens of poor families in the area. The number of fishermen, as well as the actual number of catches do not appear to compromise the natural fish stocks, although no specific capture criteria is obeyed by the fishing activity
\end{abstract}

Key words: Pantanal of Mato Grosso, traíra, piranha, subsistence fishing.

\section{RESUMO}

\section{Caracterização da pesca e do pescado de subsistência no Pantanal de Poconé (MT)}

A pesca é uma das mais antigas atividades desenvolvidas no Pantanal Mato-grossense. Na Bacia do Rio Bento Gomes (Pantanal de Poconé, MT) é freqüente a presença de pescadores em diferentes locais. Este estudo tem por objetivo descrever a atividade pesqueira na bacia, com vistas à elaboração de propostas de uso sustentável deste recurso natural. Foram catalogados 256 pescadores, a maioria pescadores de subsistência (92\%) e pescadores ocasionais ou de lufada (8\%). A traíra (Hoplias gr. malabaricus) e as piranhas (Serrasalmus marginatus, Serrasalmus spilopleura e Pygocentrus nattereri) foram as espécies mais pescadas para o consumo. A época da vazante e o início de seca é o período do ano mais procurado pelos pescadores, pois a captura é facilitada devido à concentração dos cardumes de peixe no leito do rio. O consumo destes peixes pelos pescadores e seus familiares varia de três a quatro vezes por semana, sendo duas vezes ao dia. O peixe representa um dos únicos meios de obtenção de proteína animal para dezenas de famílias carentes da região. $\mathrm{O}$ número de pescadores, bem como o rendimento atual obtido, parece não comprometer os estoques naturais, ainda que não seja obedecido nenhum critério específico para a captura dos peixes.

Palavras-chave: Pantanal de Poconé, peixe, pesca de subsistência. 


\section{INTRODUCTION}

Fishing activity is as old as man, providing food for fishermen and their families since the dawn of humanity. With the increase of human populations, fishing has grown and the need for new techniques to catch, store and distribute fish also grew in such a way that this activity now represents and important fraction of the national economy (Resende, 1988).

In the Pantanal of Mato Grosso, the largest tropical wetland area in the world, the fishing activity is practiced by a considerable human contingent, mainly composed of indigenous people, riverside populations and urban inhabitants, with different instruction levels and professions. Among them, some fish for commercial purposes, but most fish to get their daily food supply. Fish is a source of protein, besides being an attraction element used by the regional tourist industry (Catella, 1992).

In the Pantanal region, Silva (1986 apud Resende, 1988) distinguished metier fishermen, as those fishing professionally for organized groups, shops or cooperatives; and subsistence fishermen, as those fishing for their support, sometimes selling their production to neighbors or other fishermen. The same author also defined the occasional fishermen (locally called "lufada"' fishermen) as those having other subsistence activities and that only fish when there is a large number of fish in the rivers. In the Mato Grosso State, the Law of Fishing n. 6.672 of 20/10/95 recognize the categories of scientific, amateur and professional fishermen.

The fishing activity in the Pantanal of Mato Grosso exploits a resource - fish - that is practically unknown in scientific terms. Until now, 262 fish species have been recorded for the Pantanal (Britski et al., 1997), but knowledge of their natural history, behavior and ecology is reduced. In spite of the expressive number of known species, only 20 are fished commercially, possibly threatening the natural stocks in the area. The control accomplished by SIF (Service of Federal Inspection) between 1981 and 1985 showed that all the commercial fishing production in the Mato Grosso State is sustained by the capture of migratory fishes, such as the "pintado" (Pseudoplatystoma corruscans), the "cachara" (Pseudoplatystoma fasciatum) the "pacu" (Piaractus mesopotamicus), the "dou- rado" (Salminus maxillosus), the "curimbatá" (Prochilodus lineatus), the "piavuçu" (Leporinus spp.), the "jaú" (Paulicea luetkeni), the "barbado" (Pinirampus pirinampus) and others (Ferraz de Lima, 1981, 1987, 1988). However, in the Pantanal there are others species with none or very little commercial value, but that are thoroughly used by subsistence fishermen and that provide protein for inumerous poor families in the area. The present study aimed to characterize the fishing activity in the Bento Gomes River Basin, Pantanal of Mato Grosso, Central Brazil, by describing which species are caught and the intensity of fish consumption.

This information will demonstrate the importance of fish for the local population, and the need to maintain the natural stocks of low commercial value species.

\section{MATERIAL AND METHODS}

The Bento Gomes River Basin belongs to the so called Pantanal of Poconé, in the State of Mato Grosso, Central Brazil. It is located in the Northern part of the Pantanal of Mato Grosso and is of vital importance for about 40,000 people that reside in the basin. The waters of the main channel are source of drinkable water, and the Basin as a whole is used for tourism and for leisure as it is easily accessible by the Transpantaneira Road (Nogueira, 1995).

The climate of the Pantanal of Poconé varies seasonally along the year. The rain season embraces the months of October to mid March but the rainier period is from December to February. The drought season is from July to September, and the period when the water retreat after the flood goes from April to June (Nogueira, op. cit.), it is the ebb season.

The fieldwork was accomplished between May 1996 and December 1997 in two locations of the Bento Gomes River Basin: the Exhibition Park, in the city of Poconé, and the Transpantaneira Road, that were chosen because they were easily accessible by the local population and visitors (Fig. 1).

The fishermen were individually identified and questioned about their preferred fishing season and about how many people are depending on their capture to feed. 


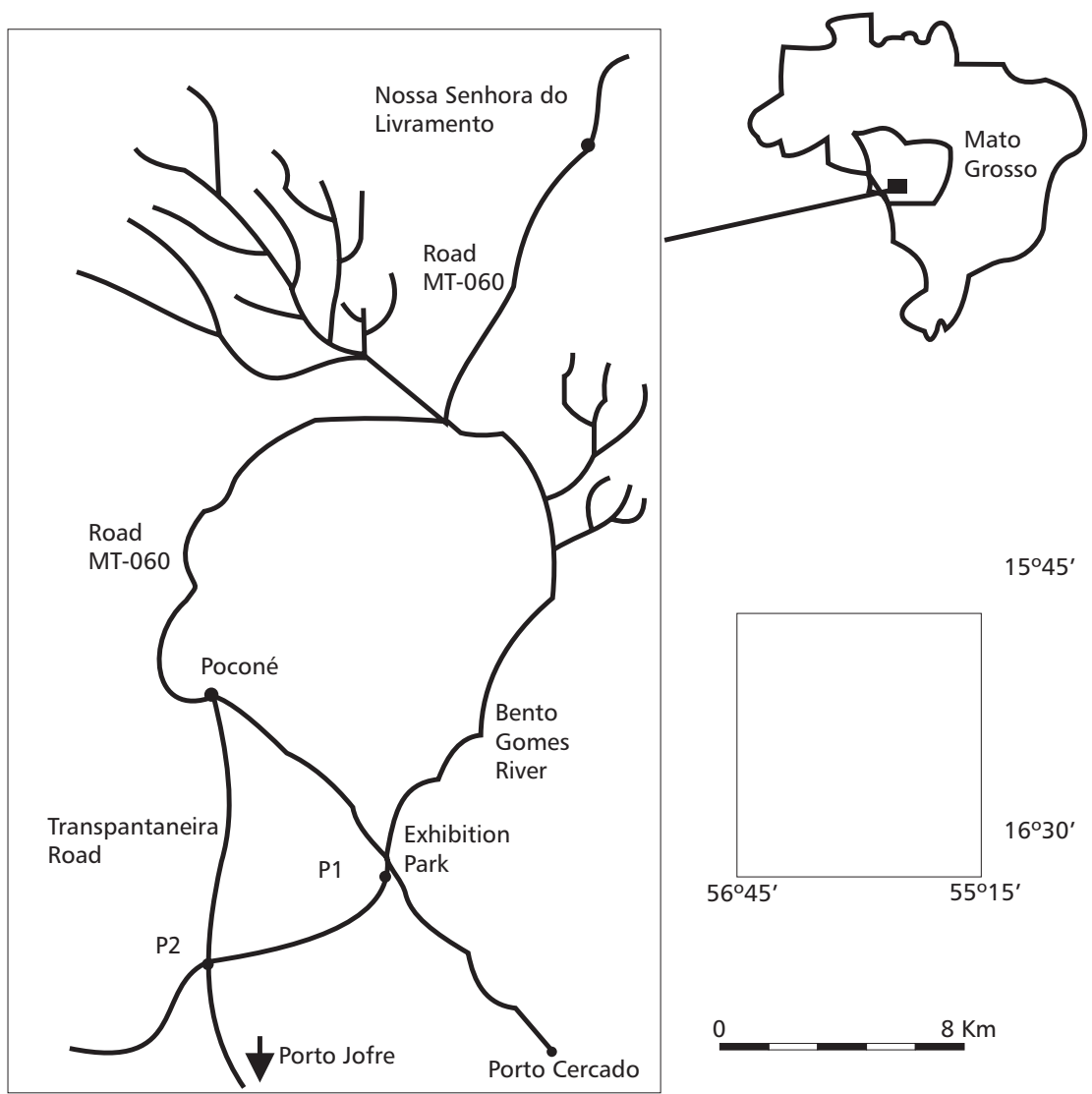

Fig. 1 - The study area: the two study locations in the Bento Gomes River Basin, Pantanal of Mato Grosso, Central Brazil.

This information was obtained minutes before they began their fishing activity or at the end of a fishing period, in different days of the week and periods of the day (morning, afternoon and evening). The fieldwork was pursued until there was no new fisherman to be investigated and lasted nineteen months.

The total fishing time of 110 fishermen was measured. The fishing utensils were also identified and quantified. Also, the daily total weight of the capture per fisherman $\left(\right.$ g.day ${ }^{-1}$. fisherman $\left.{ }^{-1}\right)$ was determined from the fish biometrics data (standard length $-\mathbf{L}_{\mathrm{s}}$ and total weight $-\mathbf{W}_{\mathrm{t}}$ ). These variables allowed the estimation of the fishing production and also the evaluation of the method's efficiency, the so called CFUE (Capture for Unit of Effort), according to Smith (1979).

The linear relationship between weight and standard length was established. This relation is described by the equation: $\mathbf{W}_{\mathrm{t}}=\mathrm{a} \mathbf{L}_{\mathrm{s}}^{\mathrm{b}}$, where $\mathbf{a}$ is the linear coefficient and $\mathbf{b}$ the angular coefficient. In order to verify the well-being of the fishes, the monthly value of the specie Condition Factor $(\mathbf{K})$ was calculated during the months when fishing was observed in the Basin.

This factor is obtained from the relationship between the weight and length: $\mathbf{K}=\mathbf{W}_{t} / \mathbf{L}_{\mathrm{s}}^{\mathrm{b}}$, where the, previously determined, coefficient $\mathbf{b}$ is an alometric value (Le Cren, 1951 apud Vazzoler, 1996). This data were analyzed in the Statistic Program - Systat 5.0.

The fish were identified using the "Fish Identification Manual for the Pantanal of Mato Grosso" (Britski et al., 1997). Some individuals were preserved in a $10 \%$ formaldehyde solution and conserved in the Laboratory of Vertebrates (Biosciences Institute, Mato Grosso Federal University, Brazil) as specimen-testimony. 


\section{RESULTS}

There are about two hundred and fifty six (256) fishermen in the Bento Gomes River Basin. About $89 \%$ of them fish mostly along the Transpantaneira Road. The subsistence fishermen prevailed $(92 \%)$, characterized by a diet strongly dependent on fish. The occasional fishermen - so called "lufada" fishermen - represent only about $8 \%$ of the total. Professional and tourist fishermen are infrequent in the study area.

The fishing activity along the Transpantaneira Road is regular. Each fisherman goes to the river about two to three times a week. In the Exhibition Park, it is less frequent, occurring only weekly, monthly, or even annually.

The main species caught in the Basin are the "traíra" (Hoplias malabaricus Bloch, 1794) and the "piranhas" (Serrasalmus marginatus Valenciennes, 1847, Serrasalmus spilopleura Kner, 1860, and Pygocentrus nattereri Kner, 1860), and they are thoroughly used as food by the fishermen and their families.

At the end of the wet season, the "carauaçú" (Astronotus ocellatus), an the "piavuçu" (Leporinus spp.) are also occasionally captured along the Transpantaneira Road and consumed as a food item. In the Exhibition Park, due to the existence of many different river habitats, fishes such as the "pacu-peva" (Metynnis spp.) and the "bagre" (Pimelodus spp.) as well as species with high commercial value such as the "pacu" (Piaractus mesopotamicus), the "pintado" (Pseudoplatystoma coruscans) and the "cachara" (Pseudoplatystoma fasciatum) are also caught. The commercial species are caught only at the ebb season, during the "lufada" period, by fishermen using canoes.

The baits are caught where fishing occurs. The most commonly used baits are the "peixecachorrinho" (Acestrorhynchus pantaneiro), the "sardinha" (Triportheus elongatus), the "lambaris" (Astyanax spp. and Moenkausia spp.), and some other Tetragonopterinae.

The species Hoplias gr. malabaricus is locally known as "traíra", "rubafo", "lobó" or "timba". It belongs to the family Erythrinidae, and is of low economic value in the Pantanal. The "piranhas" possess a relatively higher commercial value, and $P$. nattereri is the most marketable species as the individuals reach large weight and length. The subsistence fishermen consume indifferently all species of "piranhas". In the Basin, species other than "traíra" and "piranhas" account for a little more than $2 \%$ of the total capture. The fish caught in the Bento Gomes River Basin are shown in Fig. 2.

The "piranhas" and the "traíra" were captured continuously during the study period, with varying frequency, depending on the season and the number of fishermen (Fig. 3).

The linear relationship between the total weight and standard length of the seized specimens is displayed by the graphs and equations of Fig. 4.

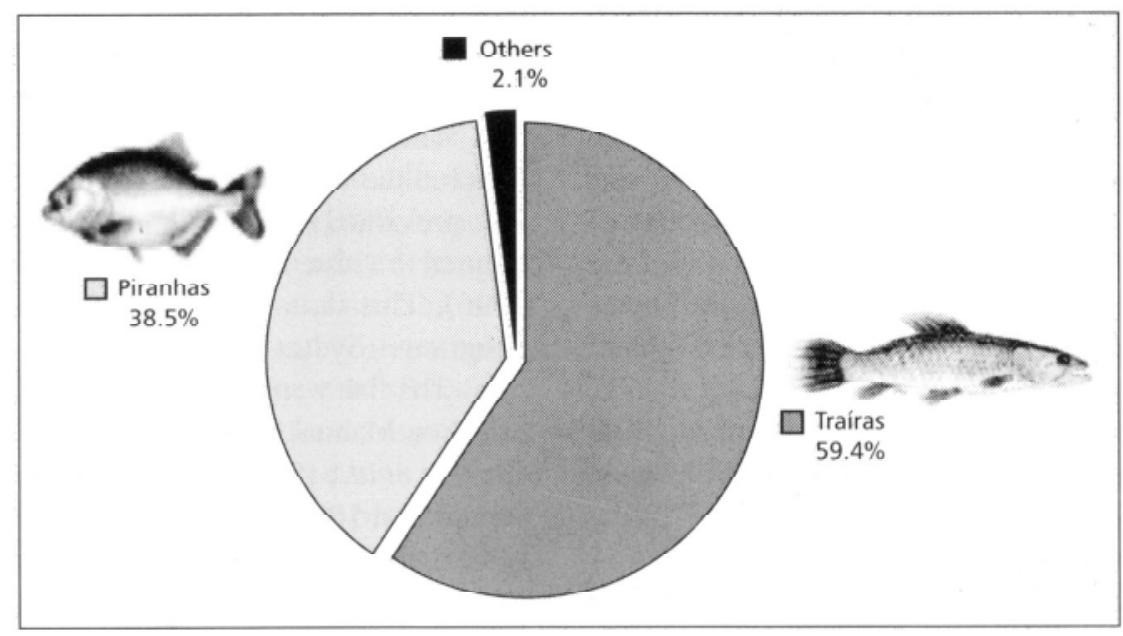

Fig. 2 - Fish caught in the Bento Gomes River Basin, Pantanal of Mato Grosso, Central Brazil. 


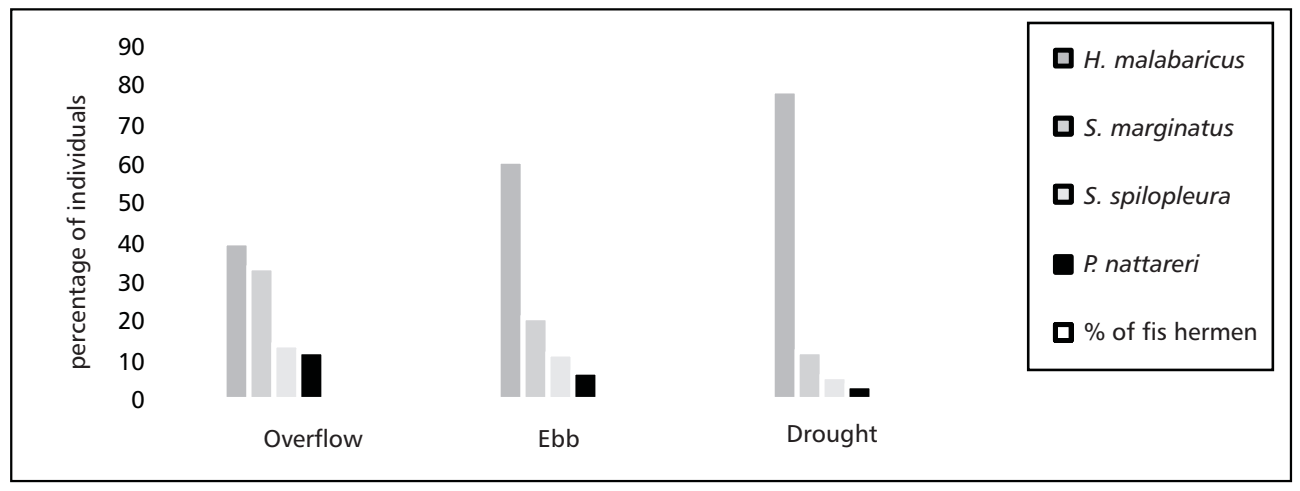

Fig. 3 - Fish capture and fishermen frequency in the Bento Gomes River Basin, Pantanal of Mato Grosso, Central Brazil.
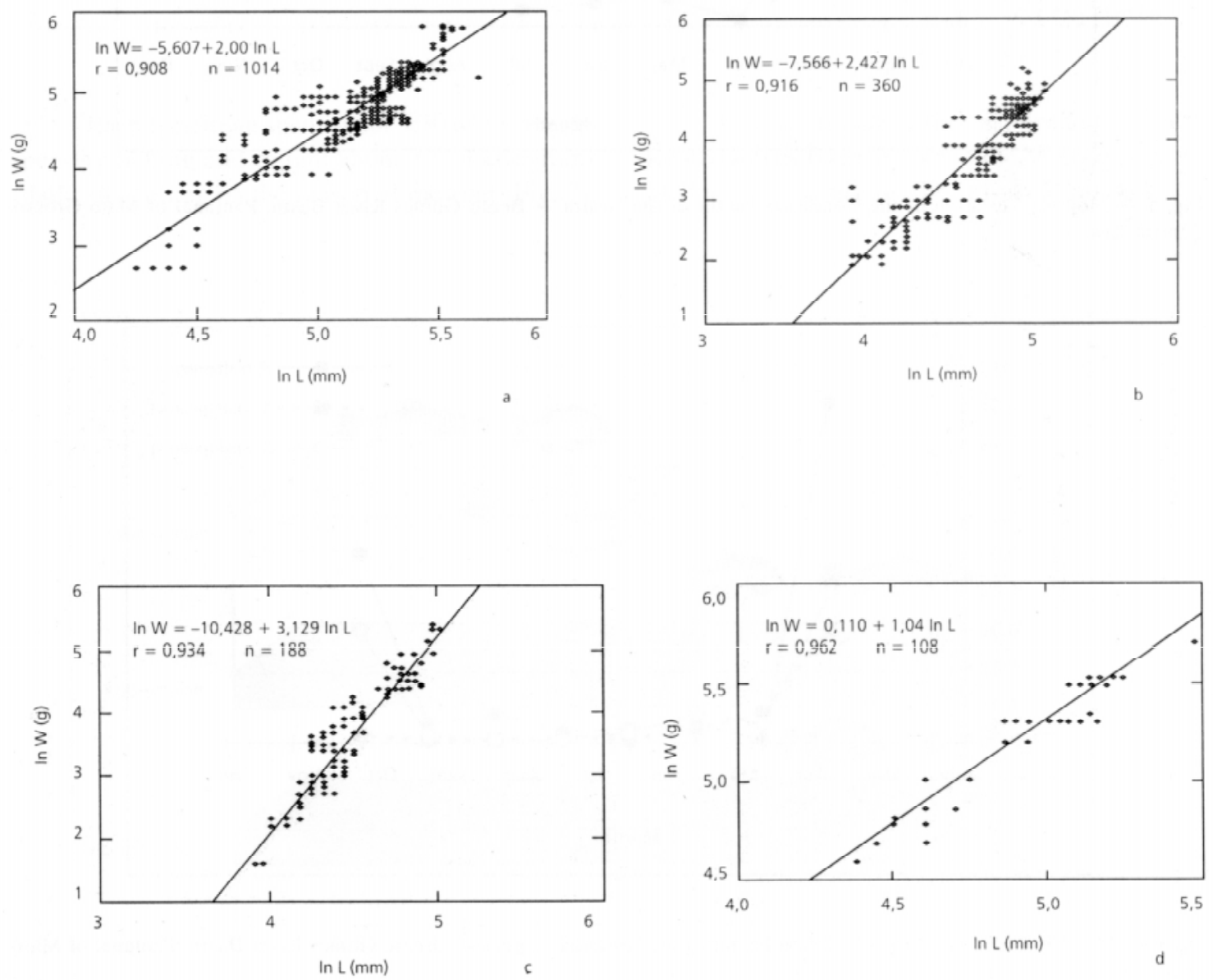

Fig. 4 - Relationship between the total weight and the standard length of H. malabaricus (A), S. marginatus (B), S. spilopleura (C) and P. nattereri (D) - Bento Gomes River Basin, Pantanal of Mato Grosso, Central Brazil. 
The calculated Condition Factors for the most consumed fish species are presented in Fig. 5 and 6. Two methods of fish catching were identified: hand line fishing and the rod fishing. The variables used for estimating the total production of subsistence fishing are listed in Table 1.

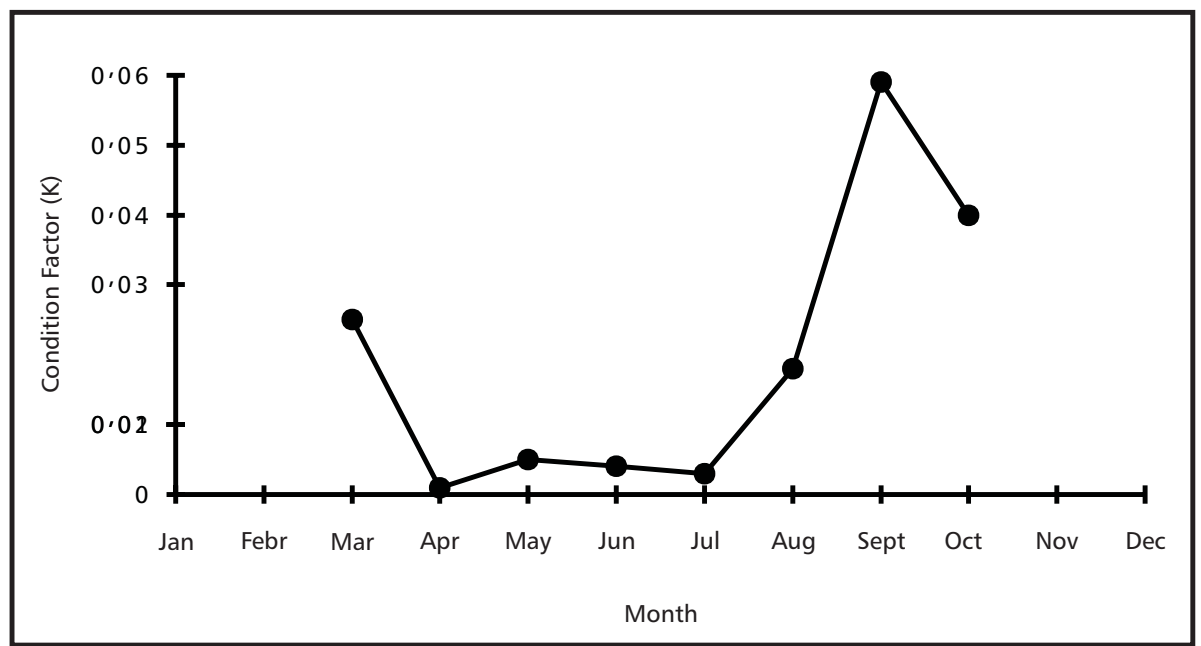

Fig. 5 - Monthly variation of the Condition Factor of the "traíra" - Bento Gomes River Basin, Pantanal of Mato Grosso, Central Brazil.

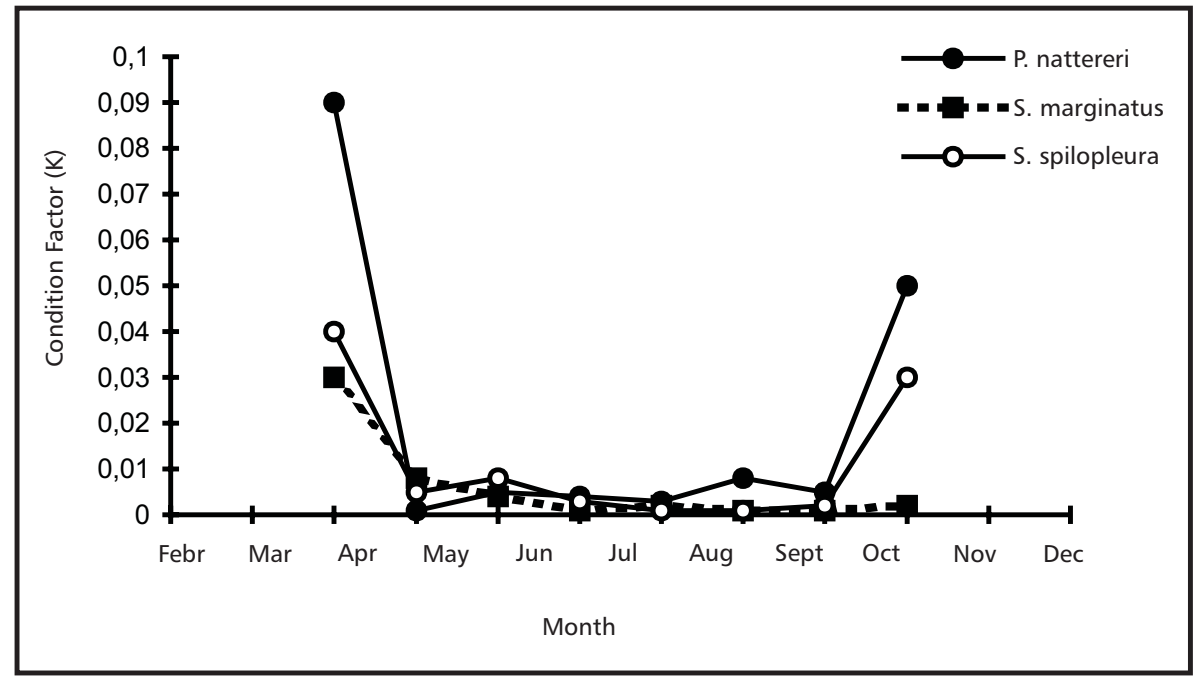

Fig. 6 - Monthly variation of the Condition Factor of the "piranhas" species - Bento Gomes River Basin, Pantanal of Mato Grosso, Central Brazil. 
TABLE 1

Variables describing the fishing activity - Bento Gomes River Basin, Pantanal of Mato Grosso, Central Brazil.

\begin{tabular}{|l|c|c|c|c|}
\hline Variables & Wet season & Ebb season & Drought season & Total \\
\hline Number of the fishermen & 20 & 79 & 11 & 110 \\
\hline Number of fishes captured & 209 & 1,203 & 255 & 1,667 \\
\hline Time spent fishing (h) & 68 & 211.5 & 40 & 319.5 \\
\hline Capture weight $(\mathrm{g})$ & $22,848.5$ & $134,405.5$ & $28,163.0$ & $185,417.0$ \\
\hline CFUE $\left(\mathrm{g} \cdot \mathrm{h}^{-1}\right)$ & 336 & 635.5 & 704.1 & 580.3 \\
\hline g.fisherman-1.h $\mathrm{h}^{-1}$ & 1.68 & 8.04 & 64.0 & 5.3 \\
\hline Number of fishhooks & 25 & 110 & 21 & 156 \\
\hline g.fishhook ${ }^{-1} \cdot \mathrm{h}^{-1}$ & 13.4 & 5.7 & 33.5 & 3.7 \\
\hline & afternoon & morning & afternoon & morning \\
Period of the day & evening & evening & afternoon \\
& & & evening \\
\hline
\end{tabular}

Each fisherman spent about 3:30 to 5:00 hours per day fishing and caught about 3 to 4 kilograms daily, depending on the season of the year (Fig. 7).
As a small part of the fish production of the Bento Gomes Basin is sold in the Municipal district of Poconé, mainly on the informal market.

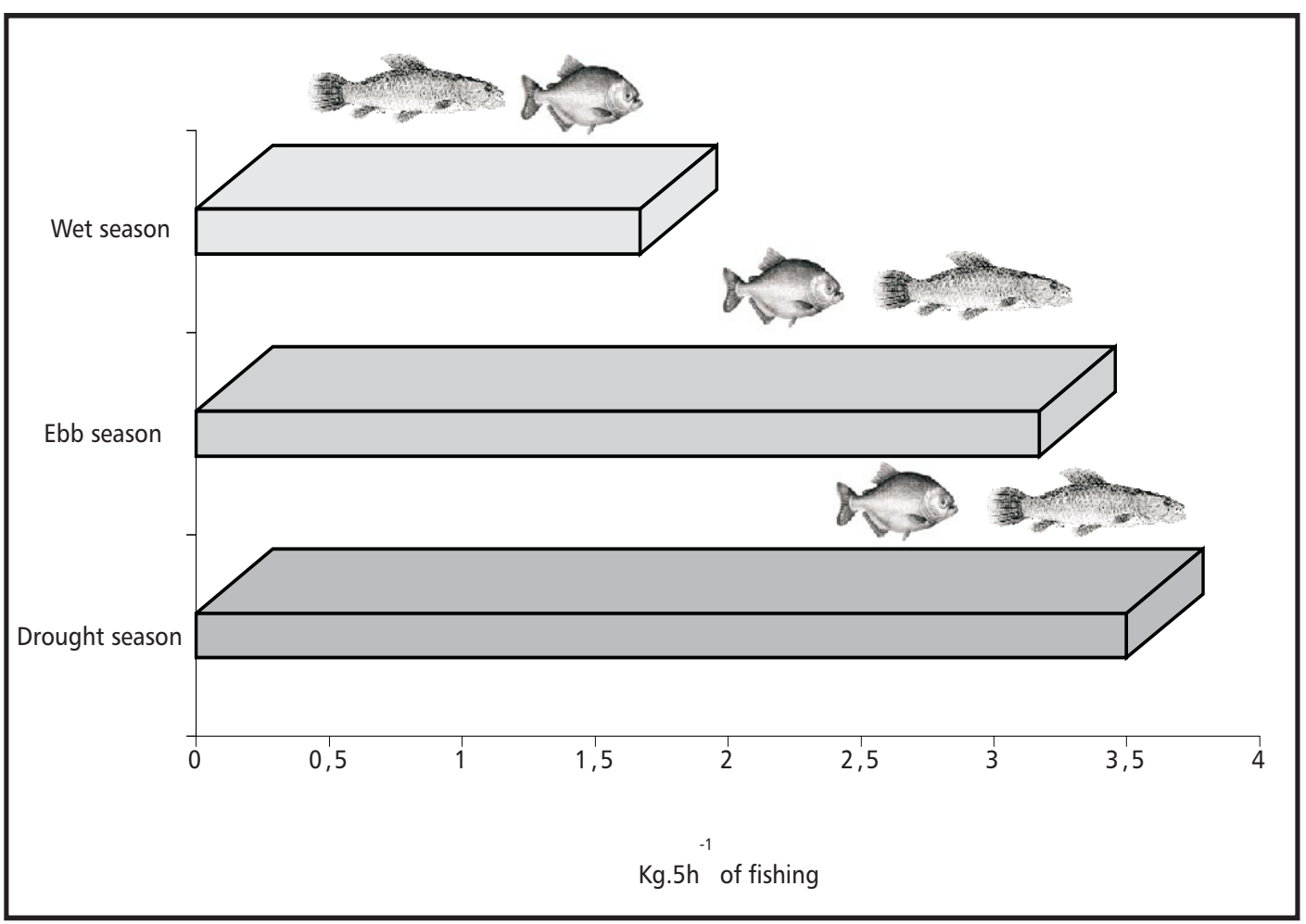

Fig. 7 - Season of the year and weight of the fish capture - Bento Gomes River Basin, Pantanal of Mato Grosso, Central Brazil. 
Most of the fish commercialization occurs mainly between the fishermen and their neighbors. However, part of the production can be sold in the Poconé weekly fair, or along the roadside during the local "rush" hour. This occasional and illegal trade, hinders the real marketed production. Most of the fish consumed in Poconé comes from other municipalities of the Pantanal, but outside the limits of the Bento Gomes River Basin.

\section{DISCUSSION}

Although the Mato Grosso State laws prohibit the commercialization of fish derived from subsistence fishing, a fraction of these catches in the Bento Gomes River Basin is being sold, even though infrequently and informally, thus corroborating the definition of subsistence fisherman elaborated by Silva (1986 apud Resende, 1988).

Subsistence fishing has been intensely practiced in the basin, and it is sometimes the only way for dozens of poor families to obtain animal protein. The growing number of families migrating in the area, along with unemployment and low purchase power, resulted in the fishermen number increase. The need for protein justifies the intensity of fish consumption. Oliveira et al. (1990) verified that fish is the second most important diet item in this area.

The prevalance of "traíras" and "piranhas" in the Bento Gomes River Basin, probably discouraged the professional fishermen, as these are not commercially attractive species. However, for the subsistence fishermen the protein supply matters much more than the species. Interestingly, Marins (1982) shows, that in some areas, even if the fishermen have other fish species to eat, they prefer "piranhas", because they are renowned as a tonic and are used by the convalescents and also as an aphrodisiac. In some cases, the "piranhas" soup replaces the traditional chicken soup to fortify the riverside pregnant mothers.

The "traíra" capture was more pronounced during the ebb season, specially in the beginning in the drought season, confirming the observations of Resende et al. (1996). This author also verified that, as the dry season progresses and the aquatic environment regresses, more and more "traíra" individuals are encountered in the main river channel. This fish possesses a characteristic beha- vior during the ebb season. Oliveira (1994) and Machado \& Sazima (1992), studying its habits and alimentary behavior, observed that it ambushes the preys near the channel margins and succeeds in eating great amounts. It thus accumulate fat (energy) for the coming drought season, when predation conditions are not favorable. The presence of large "traíra" groups facilitates the catch and explains why the number fishermen is elevated.

Though the "traíras" do not have any special morphological adaptations to the hypoxic conditions prevailing during most of the dry season (Carter \& Beadle, 1931, and Wilimer, 1934, apud Riggs et al., 1978), they are able to survive under extremely low levels of dissolved oxygen, using only aquatic breathing (Parma de Croux, 1983). This aspect probably allows them to continue being easily captured by the fishermen during the dry period, when the dissolved oxygen deficit is greater.

According to Braga (1976 apud Marins, 1982), the "piranhas" also support dissolved oxygen concentrations below the minimum generally required by other species. However, studies with Pygocentrus nattereri, by Bittencourt \& Merona (1997), showed an apparent relationship between the seasonal variation of the water level and the population size.

During the drought season, at low water levels, when oxygen concentrations are usually low, fish abundance is also reduced.

Therefore, in the Bento Gomes River Basin, the fish community composition is influenced by the season and the characteristics of each species. As a consequence, the fishermen organize themselves according to the movement and concentration of the shoals. The category of occasional fishermen, for example, only go fishing during the periods when there are large number of fishes in the river, and they prefer to catch species renowned as "noble".

The analysis of the fish biometrics data reveals that the fishermen catch relatively low size individuals, when compared to the literature numbers, considering the same fishing methods (Table 2).

Although the fish sexual maturation was not analyzed, it is possible to consider that the caught fish did not reach full maturation based on the size of the individuals. 
TABLE 2

Maximum fish length (mm) for individuals captured in the Bento Gomes River Basin, according to different authors.

\begin{tabular}{|c|c|c|}
\hline Species & Maximum length $\mathbf{( m m )}$ & Authors \\
\hline H. malabaricus & 290 & This study \\
& 500 & Britski et al. (1997) \\
& 350 & Sazima \& Machado (1990) \\
\hline S. marginatus & 156 & This study \\
& 270 & Britski et al. (1997) \\
& 230 & Sazima \& Machado (1990) \\
\hline S. spilopleura & 165 & This study \\
& 230 & Britski et al. (1997) \\
& 230 & Sazima \& Machado (1990) \\
\hline P. nattereri & 240 & This study \\
& 500 & Britski et al. (1997) \\
& 270 & Sazima \& Machado (1990) \\
\hline
\end{tabular}

Only through studies about the reproductive biology will it be possible to accurately determine the breeding period of the basin species. This subject is very complex, Vazzoler (1996) studying the reproductive biology of some species of the Paraná River, verified that individuals of H. malabaricus presented the first reproduction period at a lenght of $141 \mathrm{~mm}$. Barbieri (1989), in the "Monjolinho" reservoir in São Paulo, determined a size of 167 $\mathrm{mm}$ for the first sexual maturation of the same species, corresponding to the second year of the fish life. Lowe-McConnell (1964 apud Barbieri, op. cit.) estimated a standard length of $200 \mathrm{~mm}$ for the first reproduction period of "traíras" from the Savanna Ruppunini (Guyana). Caramaschi \& Godinho (1982), for another reservoir, observed that the first sexual maturation happened at about $135 \mathrm{~mm}$ (total length). For the "piranhas", S. marginatus and S. spilopleura, Vazzoler (1996) indicated that the first sexual development happened at a length (total) of about 92 and $90 \mathrm{~mm}$, respectively. In this context, Caramaschi (1979) explains that some factors such as the photoperiod and high temperature can favor the sexual precocity.

The value of the Condition Factor for a particular species can be related to the sexual development, fat accumulation, susceptibility to environmental changes, alimentary conditions (degree of stomach repletion), age and population density (Barbieri \& Verani, 1987; Barbieri et al., 1982). The statistical analysis revealed a marked monthly variation of the physical conditions of the species caught in the Bento Gomes River Basin.

Assuming that the Condition Factor can reflect the reproductive period of a species, and considering that the "traíra" (H. gr. malabaricus) showed a better physiological state during the dry season, when the adults are captured by the fishermen, it is possible to say that this is probably the reproductive period. This species does not modify its alimentary habits during the reproductive period (Barbieri et al., op. cit.), and this can also contribute to the increase of its Condition Factor.

The condition Factors of the two "piranhas" species captured in the Bento Gomes River Basin were similar. Both exhibited better physiological conditions during the months when fishing did not occur. This probably contributed to the maintenance of individuals apt to reproduce in this environment.

Hand line and rod fishing (the only methods allowed by the legislation of Mato Grosso - Law of the Fishing n. 6,672, of October 20, 1995, article $8^{\text {th }}$ ) are cheap, easy to acquire and require little ability to use. In spite of the low production obtained with this equipment (580.3 g.h ${ }^{-1}$ ), when compared to other methods (ex. casting net), it is efficient and can meet the subsistence fishermen needs, as it can be used during different periods of the day and the year, and under various environmental conditions. The occasional fishermen, using the same instruments, are able to obtain a larger biomass, not only because of their access to boats and refrigeration, which allow them to store more 
fish, but also because they can stock larger amounts of "noble" species they are more interested in.

As fishing is essentially for subsistence - the amount of angled fish was $5.3 \mathrm{~g}$.fisherman ${ }^{-1} \cdot \mathrm{h}^{-1}-$ and the current number of fishermen is low, it probably does not affect the renewal of natural stocks. However, the data reveal that when the number of fishermen increases, the total captured weight tends to fall, suggesting that overfishing might be occurring.

The fishing production of the Bento Gomes River Basin comes essentially from subsistence fishing, an activity of increasing importance for the poor population of the municipal district. Although the fishermen capture mostly "piranhas" and "traíras", it does not seem so far, there is a risk of reducing their natural stock. However, it is necessary to point out that there are no criteria for the minimum capture size of these species in the basin. Between November and February fishing is prohibited, because this is known reproduction period for most fish species, although it does not coincide with the real reproductive period of the "piranhas" and "traíras". Further studies on the behavior of these species are needed in order to elaborate better fishing control criteria to ensure the sustainable use of this fish resource. Moreover, other high impact anthropic activities such as gold mining should be strictly monitored, in order to maintain the ecological integrity of the system and the natural stocks.

Acknowledgments - This is the contribution number 40 of the Pantanal Ecology Project - (UFMT, IB/Max Planck Institut fur Limnologie, Plöen), supported by the Studies of Human Impact on Forest and Floodplains in the Tropics (SHIFT) Program (Env. 13), a Brazil-Germany technical-scientific Cooperation Program (IBAMA/CNPq/DLR-Germany). We are grateful to all those who collaborated to this study, in especial Dr. William Severi and Dr. Pierre Girard, for their suggestions.

\section{REFERENCES}

BARBIERI, G., VERANI, J. R. \& BARBIERI, M. C., 1982, Dinâmica quantitativa da nutrição de Hoplias malabaricus (Bloch, 1974) (Pisces, Erythrinidae), na Represa do Lobo (Brotas-Itirapina, SP), Rio de Janeiro. Rev. Brasil. Biol., 42(2): 295-302.

BARBIERI, G. \& VERANI, J. R., 1987, O fator de condição como indicador do período de desova em Hypostomus aff. plecostomus (Linnaeus, 1758) (Osteichthyes, Loricariidae), na Represa do Monjolinho (São Carlos). Ciência e Cultura 39(7): 655-658.
BARBIERI, G., 1989, Dinâmica da reprodução e crescimento de Hoplias malabaricus (Bloch, 1974) (Osteichthyes, Erythinidae) da Represa do Monjolinho, São Carlos, SP. Rev. Bras. Zool., 6(2): 225-233.

BITTENCOURT, M. M. \& MERONA, B., 1997, Inter-annual variability of Red Piranha abundance (Pygocentrus nattereri Kner, 1860). In: International Symposium Biology of Tropical Fishes. Manaus, Amazonas, p. 23.

BRITSKI, H. A., SILIMON, K. Z. S. \& LOPES, B. S., 1997, Manual de Identificação de peixes do Pantanal Matogrossense. Corumbá, EMBRAPA, 62p.

CATELlA, A. C., 1992, Estrutura da comunidade $e$ alimentação dos Peixes da Baía da Onça, em lagoa do Pantanal do Rio Aquidauana, MS. Dissertação de Mestrado, Unicamp, Campinas, SP, 217p.

CARAMASHI, E. M. P., 1979, Reprodução e alimentação de Hoplias malabaricus (Bloch, 1794) na Represa do Rio Pardo (Botucatu, SP) (Osteichthyes, Cypriniformes Erythrinidae). Dissertação de Mestrado, PPG-ERN, Universidade Federal de São Carlos, 144p.

CARAMASHI, E. M. P. \& GODINHO, A., 1982, Reprodução e alimentação de Hoplias malabaricus (Bloch, 1794) na Represa do Rio Pardo (Botucatu, SP): histologia e escala de maturação do ovário. Rev. Brasil. Biol., 42(3): 635-640.

FERRAZ DE LIMA, J. A., 1981, A pesca no Pantanal de Mato Grosso, Rio Cuiabá: Aspecto da produção pesqueira. In: CONGRESSO BRASILEIRO DE ENGENHARIA DE PESCA, 2, Recife, pp. 503-516. Anais...

FERRAZ DE LIMA, J. A., 1987, A pesca no Pantanal de Mato Grosso (Rio Cuiabá: importância dos peixes migradores). Bíblia do Pescador, 7(7): 82-83.

FERRAZ DE LIMA, J. A., 1988, A Tecnologia de pesca no Centro-Oeste do Brasil (Bacia do Alto Paraguai: Pantanal de Poconé). AEP-CE, Fortaleza, p. 695. Anais...

MACHADO, F. A. \& SAZIMA, I., 1992, Atividade de caça em peixes Erythrinidae: Hoplias malabaricus e Hoplerythrinus unitaeniatus no Pantanal. In: Congresso Brasileiro de Zoologia, 19. Belém, Pará, p. 35.

MARINS, R. V., 1982, Biologia e auto ecologia das piranhas do Pantanal Mato-grossense, Bacia do Alto Rio Paraguai. EFRIMAT, Cuiabá, 43p.

OLIVEIRA, E. F., CASTRO e SILVA, E., OZAKI, S. K., FERREIRA, M. S. \& YOKOO, E. M., 1990, Mercúrio via cadeia trófica na Baixada Cuiabana: ensaios preliminares. In: SEMINÁRIO NACIONAL SOBRE RISCOS E CONSEQÜENNCIAS DO USO DO MERCÚRIO, Brasília, DF. Rio de Janeiro, FINEP/IBAMA/CNPq/Ministério da Saúde, pp. 202-210. Anais...

OLIVEIRA, R. D., 1994, Hábitos e comportamento alimentar da traíra, Hoplias malabaricus (Erythrinidae), em algados de vazante, Município de Santo Antônio do Leverger-MT. Monografia, Cuiabá, MT, UFMT, 26p.

PARMA de CROUX, M. J., 1983, Nivel de oxígeno y mínimo de supervivencia de Hoplias malabaricus (Bloch, 1974) (Pisces, Erythinidae). IHERINGIA. Sér. Zool., 63: 91-101. 
RESENDE, E. K., PEREIRA, R. A. C., ALMEIDA, V. L. L. \& SILVA, A. G., 1996, Alimentação de peixes carnívoros da planície inundável do Rio Miranda, Pantanal, Mato Grosso do Sul, Brasil. EMPRAPA-CPAP, Corumbá, 36 p. (Boletim de Pesquisa, 03).

RESENDE, E. K., 1988, Recursos pesqueiros do Pantanal: diagnóstico e propostas de pesquisa. EMBRAPA/CPAP, Corumbá, 51p.

RIGGS, A., FYHN, H. J., FYHN, U. E. H. \& NOBLE, R. W., 1978, Estudos sobre sangue e hemoglobinas de peixes amazônicos. In: Estudo das propriedades funcionais da hemoglobina de Hoplias malabaricus e Hoplerythrinus unitaeniatus. Acta Amazonica., 8(4): 251-257
SAZIMA, I. \& MACHADO, F. A., 1990, Underwater observations of piranhas in western Brazil. Envirom. Biology of Fishes, 28: 17-31.

SMITH, N. J. H., 1979, A pesca no Rio Amazonas. INPA, Manaus, $154 \mathrm{p}$.

VAZZOLER, A. E. A. M., 1996, Biologia da reprodução de peixes teleósteos: teoria e prática. EDUEM, Maringá, $169 \mathrm{p}$. 